\title{
Mechanisms of Acute Cocaine Toxicity
}

\author{
Kennon Heard ${ }^{*}, 1,2$, Robert Palmer ${ }^{1}$ and Nancy R. Zahniser ${ }^{3}$
}

\author{
${ }^{1}$ Rocky Mountain Poison and Drug Center, Denver Health, ${ }^{2}$ Division of Emergency Medicine, University of Colorado \\ Denver School of Medicine, ${ }^{3}$ Department of Pharmacology and Neuroscience Program, University of Colorado Denver \\ School of Medicine, CO, USA
}

\begin{abstract}
Patients with acute cocaine poisoning present with life-threatening symptoms involving several organ systems. While the effects of cocaine are myriad, they are the result of a limited number of cocaine-protein interactions, including monoamine transporter, neurotransmitter receptor and voltage-gated ion channels. These primary interactions trigger a cascade of events that ultimately produce the clinical effects. The purpose of this article is to review the primary interactions of cocaine and the effects that these interactions trigger. We also describe the progression of symptoms observed in cocaine poisoning as they relate to serum cocaine concentrations.
\end{abstract}

Keywords: Cocaine poisoning, dopamine receptor, serotonin receptor, sigma receptor, acetylcholine receptor.

\section{INTRODUCTION}

\section{Introduction/Background}

Cocaine use contributes to tens of thousands of emergency department (ED) visits and hundreds of deaths each year. While cocaine use is coincident in most cases, (e.g. trauma, psychiatric or infections), cocaine poisoning accounts for many of these visits. The major effects of cocaine poisoning include CNS effects such as agitation, seizures and psychosis, and cardiovascular effects such as dysrhythmias, myocardial infarction and cardiovascular collapse.

The pharmacology of cocaine is complex with effects occurring simultaneously in several organ systems. However, the initial event for all of these systems is simple; cocaine binds to membrane bound proteins including transporters, receptors and voltage gated ion channels. Once the interaction occurs, a specific signal is triggered (or inhibited), and the combination of these effects produces the clinical manifestations of cocaine poisoning. The cocaine-protein interaction is dependent on two main factors: the concentration of cocaine (assuming that the protein concentration is constant) and the affinity between cocaine and the protein. By describing serum cocaine concentrations and the affinity of cocaine for relevant proteins, we will describe the mechanisms of acute cocaine poisoning to assist clinicians to understand the progression of cocaine poisoning and to suggest potential treatments for acute cocaine poisoning.

\section{Cocaine Concentrations and Clinical Effects}

Serum cocaine concentrations are determined by four main factors: 1) the dose; 2) the route of administration; 3) the binding of cocaine to plasma proteins; and 4) the rate of metabolism.

*Address correspondence to this author at the Rocky Mountain Poison and Drug Center, 777 Bannock St. MC 0180, Denver, CO 80204, USA; Tel: 303 739-1475; Fax: 303 739-1264; E-mail: Kennon.Heard@UCHSC.edu
Cocaine concentrations have been determined following administration in controlled clinical settings, in recreational users who are evaluated in the ED, and in post-mortem studies. The most reproducible data have been obtained in controlled clinical studies where known doses of cocaine are administered to research subjects. This allows systematic determination of the effects of dose and route of administration on concentrations. Peak serum cocaine concentrations measured after intravenous administration have been described in several studies. One study reported serum concentrations of 2.5 and 10 microM after doses of 100 and $200 \mathrm{mg}$ respectively [1]. Most studies have used lower doses and have demonstrated that intravenous administration of recreational doses of cocaine $(20-50 \mathrm{mg}$ ) will produce serum concentrations between 0.4 and 1.5 microM [2-5]. There is a between-subject variation of two to threefold in peak serum concentrations for a given dose. Peak serum concentrations after smoking 40 to $50 \mathrm{mg}$ of cocaine base or nasal insufflation of $100 \mathrm{mg}$ of cocaine hydrochloride are also around 1 microM $[2,6]$.

While studies of volunteers who receive a known cocaine dose provide the most precise measurement of the effect of dose and route on serum concentrations, they may not reflect serum concentrations that occur in cocaine-abusing patients. Studies of cocaine concentrations in clinical settings (primarily patients presenting to EDs for medical care) may offer a better picture of "real world cocaine concentrations", but they have several limitations and must be interpreted carefully. First, the precise doses of cocaine are unknown. Second, samples are not conducted at specific times after the dose so the exact relationship of the dose and concentration cannot be defined. Finally, because cocaine is metabolized rapidly and because metabolism can continue in vitro after sample collection, careful sample handing is required to obtain measurements that actually reflect the patient's serum cocaine concentration. There are two major studies where serum cocaine concentrations were measured in a cohort of ED patients. In the largest series $(n=111)$, serum concentra- 
tions in emergency department patients averaged approximately 0.9 microM but varied dramatically (standard deviation of $=1.6$ microM !). The highest concentration in a surviving patient (who displayed minimal symptoms of toxicity) was 120 micromolar [7]. A second small series $(n=29)$ reported detectable concentrations in only 3 patients $(0.05$ to 0.4 microM) [8], while a third series $(n=19)$ was unable to detect cocaine in any patient [9].

Postmortem cocaine concentrations are susceptible to the same limitations as clinical studies, and may be further altered by post-mortem metabolism and redistribution. It is likely that many reported concentrations do not accurately reflect concentrations at the time of death [10]. Serum cocaine concentrations exceeding 1000 microM [11] have been reported following acute fatal overdose, although one series of 26 cases reported a mean concentration of 21 microM (range 0.3 to 70 microM) in deaths where cocaine was the only drug detected [12]. A second series compared cocaine concentrations of patients who died from trauma (and incidentally used cocaine) to cocaine concentrations of patients who died from cocaine poisoning. The mean concentration in cocaine-poisoned patients was 3.6 (range 0.03 to $62 \mathrm{mi}$ croM), compared to a mean of 1.6 (range 0 to 16) microM for trauma patients [13]. These samples were obtained on average 18 hours after death, so it is likely that they are not peak concentrations.

Overall, the similar values observed in controlled studies in the best described ED cohort suggests that recreational cocaine abusers have peak serum concentrations between 0.5 and 5 microM. However, some patients survive overdoses with much higher peak serum concentrations. Patients who die of acute cocaine poisoning overdose likely have peak serum cocaine concentrations exceeding 10 microM, although this estimation is limited by the quality of available data.

\section{Factors Affecting Cocaine Concentrations}

The absorption of cocaine is rapid with nasal insufflation and smoking, and immediate with intravenous administration. In volunteer studies, the maximum concentration occurs 20 to 40 minutes after nasal insufflation and 5 minutes after smoking [2]. Following intravenous administration, cocaine has a distribution half-life of 11 minutes and an elimination half-life of approximately 80 minutes [2]. The time to peak subjective effects is slightly different than the pharmacokintetic data. Onset is fastest for smoked cocaine (mean 1.4 $\mathrm{min}$, SD $0.5 \mathrm{~min}$ ), slightly longer for intravenous cocaine (mean $3.1 \mathrm{~min}$, SD $0.9 \mathrm{~min}$ ) and much longer for intranasal cocaine (mean 15 min SD 8 minutes) [14]. While the pharmacokinetic data are generally consistent in healthy volunteer studies, there are several clinical scenarios where cocaine pharmacokinetics may be altered.

One common clinical setting where cocaine kinetics could be altered is with repetitive dosing, as commonly occurs during a cocaine binge. Animal studies suggest repetitive cocaine dosing produces higher serum and brain concentrations, compared to single dose administration [15]. However, one human study found that when serial doses of cocaine are administered, the incremental increase serum cocaine concentrations was proportional to the dose administered regardless of starting cocaine concentration [16]. This study also reported that patients rapidly developed tolerance to the heartrate effects of cocaine [16], suggesting that cocaine tolerance is a pharmacodynamic rather than pharmacokinetic effect.

Animal models suggest co-administration of ethanol alters the pharmacokinetic parameters of cocaine $[17,18]$. Controlled human studies have shown that ethanol coadministration increases the maximum serum concentration of cocaine by 5 to $40 \%$ [19-21]. Co-administration of cocaine and alcohol alters the metabolism of cocaine and promotes the production of cocaethylene, an active cocaine metabolite with cardiovascular and neurological effects [19, 22].

The effects of sex hormones on cocaine concentrations have been studied in both animals and humans. Male mice metabolize oral cocaine more slowly than female mice [23]. Rat studies have found lower doses are required to produce toxicity in males [24] and that males produce more benzoylecgonine [25] and have peak cocaine concentrations approximately $50 \%$ higher than females following iv administration [26]. Human studies have similar findings; cocaine concentrations in males are $50 \%$ higher following a weight adjusted dose [27]. Males may even be more sensitive to cocaine-alcohol interactions [28].

In summary, there are several clinical factors that may alter the pharmacokinetics of cocaine. These factors likely contribute to the inter-subject variability in sensitivity to cocaine. However, it is important to note that the increase in serum concentrations for each of these factors is less than $60 \%$, well within the inter-subject variation reported in dosing studies and well below the 20 -fold increase that would be required to achieve the mean cocaine concentrations reported in post-mortem samples from overdose patients.

\section{Cocaine-Protein Binding}

Cocaine binds to several proteins, including monamine transporters, neurotransmitter receptors, plasma proteins, voltage gated ion channels, and metabolic enzymes. The affinity of cocaine is different for each target protein and is quantified by an affinity constant denoted either $\mathrm{Ki}$ (for transporters, receptors, channels and enzymes) or $\mathrm{Kd}$ (for binding proteins). These values are the concentration at which half of the cocaine is bound to protein and half is unbound. A low $\mathrm{Ki}$ or $\mathrm{Kd}$ means that the protein has a high affinity for cocaine. When concentrations are near the $\mathrm{Ki}$ or $\mathrm{Kd}$, the slope of the concentration-binding curve is usually very steep so that small changes in concentration will cause large changes in the amount of cocaine interacting with the protein. An general example of a showing the relationship between drug binding and activity is shown in Fig. (1). At concentrations more than 10 -fold below the $\mathrm{Kd}$, very few sites are occupied, while at concentrations more than 10 -fold above the $\mathrm{Kd}$, essentially all receptor sites will be occupied and the maximum effect for that receptor will occur. Although the $\mathrm{Ki}$ and the $\mathrm{Kd}$ are determined in vitro and cannot be translated directly to in vivo receptor occupancy, they do allow a relative comparison of receptor occupancy at a given drug concentration.

Cocaine-protein binding triggers a cell-specific response. The clinical effects of cocaine are manifest in several organ systems, including the brain, cardiovascular, immune and 
hematological systems. While the ultimate manifestations are diverse and widespread, cocaine binds to a limited number of proteins. The common effects of cocaine occur when cocaine binds to the three monoamine transporters on nerve terminals: the serotonin transporter (SERT), the dopamine transporter (DAT) and the norepinephrine transporter (NET). In vivo studies have shown that these transporters have similar $\mathrm{Ki}$ values for cocaine: 0.140 .64 and 1.6 microM for the SERT, DAT and NET respectively [29]. Once bound to these transporters, cocaine prevents the reuptake of the neurotransmitters from the extracellular space. The increased concentration of the neurotransmitter in the synapse leads to increased activation of post-synaptic receptors.

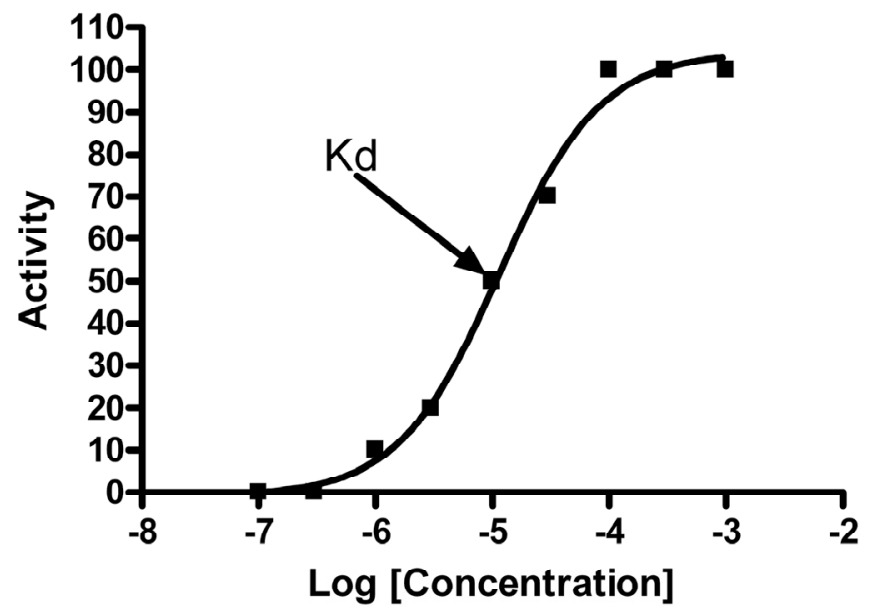

Fig. (1). Idealized curve showing the relationship between concentration and activity for a drug. The $\mathrm{Kd}$ is the drug concentration where the activity is $50 \%$ of maximum.

Cocaine binds directly to two classes of neurotransmitter receptors: muscarinic acetylcholine and sigma receptors. In rats, cocaine has an Ki of 19 microM for heart M2 acetylcholine receptors, a $\mathrm{Ki}$ of 24 microM for M2 muscarinic receptors in brain and a $\mathrm{Ki}$ of 40 microM for M1 muscarinic receptors in brain [30]. Studies have shown cocaine binds human muscarinic receptors [31]. Finally, cocaine binds to sigma receptors (in rat cerebellum) with a $\mathrm{Ki}$ of $6.7 \mathrm{microM}$ [32].

In addition to interacting with neurotransmitter transporters and receptors, cocaine binds to several voltage-gated ion channels. This interaction is responsible for the local anesthetic effect of cocaine. While there are voltage gated ion channels in nerve and cardiac tissue, local anesthetic effects are not thought to contribute significantly to the effects of cocaine on the brain $[33,34]$. However, local anesthetic effects are responsible for cocaine cardiotoxicity.

In isolated cardiac myocytes (with serum proteins), cocaine binds primarily to the inactivated state of sodium channels with a $\mathrm{Ki}$ of 8 microM [35]; a concentration of 50 microM decreases the inward sodium current by $50 \%$ [36]. The cocaine-sodium channel interaction is highly dependent on extracellular $\mathrm{pH}$ and sodium channel blockade increases as $\mathrm{pH}$ falls below the physiologic range [37]. Cocaine also binds and inhibits cardiac potassium rectifier channels with and affinity of 5.6 microM, and a concentration of approximately 5 microM decreased outward potassium current by $50 \%[38,39]$. Finally, a single report found that cocaine increases the probability of channel opening and prolongs the duration of opening of L-type calcium channels in isolated cardiac myocytes at a concentration of 0.3 microM [40].

Two additional cocaine-protein interactions are relevant to cocaine toxicity. The first interaction is with plasma proteins. Cocaine binds to alpha 1 acid glycoprotein (A1AG) and to albumin $[41,42]$. A1AG is a plasma protein present in a concentration of 25 microM that has a high affinity $(\mathrm{Ka}=0.5 \mathrm{microM})$ for cocaine. Albumin has a much lower affinity for cocaine, and only $10 \%$ of cocaine is bound to albumin. Overall, human serum can bind approximately 10 micromoles of cocaine per liter [41]. When the concentration exceeds the binding capacity, free cocaine concentrations increase dramatically (Fig. 2). In this experiment, doubling of the cocaine concentration from 0.033 to 0.066 microM increased free cocaine concentrations threefold [41]. Finally, cocaine binding to serum proteins is highly $\mathrm{pH}$ dependent, An in-vitro model suggests that the concentration of free cocaine may increase by $50 \%$ if the serum $\mathrm{pH}$ falls from 7.5 to 7.0 (for example, after a seizure) [42].

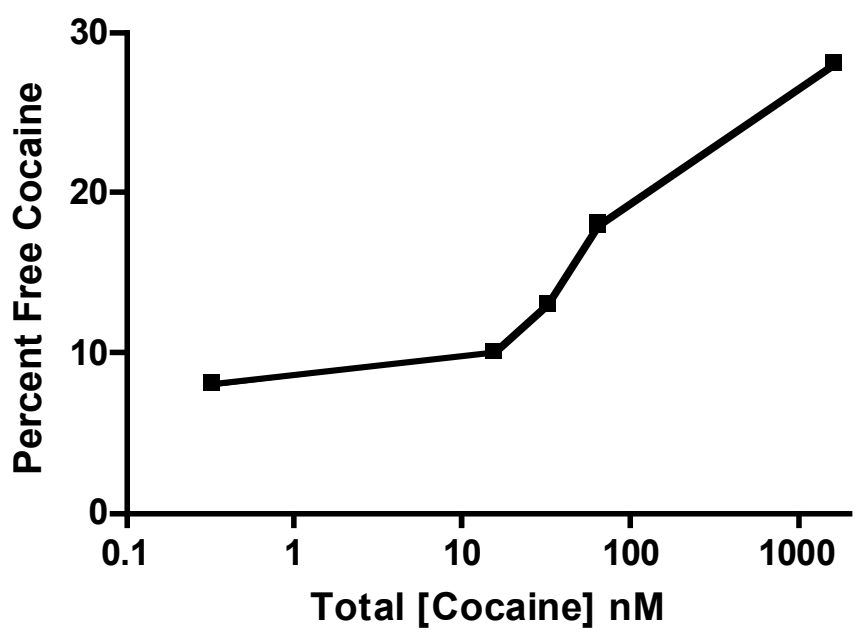

Fig. (2). Free cocaine as a function of total cocaine. This graph demonstrates saturation at high concentrations. Data are adapted from [41].

Cocaine is metabolized by several enzymatic pathways and also by non-enzymatic hydrolysis. Minor pathways include metabolism by the CYP-3A to norcocaine [43]. This metabolite may be responsible for the hepatotoxicity of cocaine [44], but the low levels formed are unlikely to contribute to systemic effects.

The majority of cocaine is metabolized by both enzymatic and non-enymatic hydrolysis to benzoylecgonine [45, 46]. The enzymatic hydrolysis of cocaine to benzoylecgonine is by the hepatic enzyme human cholinesterase (hChE1) [47]. In plasma, cocaine is metabolized by butylcholinesterase (pseudocholinesterase) to ecgonine methyl ester [47]. The affinity $(\mathrm{Km})$ of butylcholinesterase for cocaine is approximately 11 microM, whereas the affinity of hChE1 is 116 microM [45] and the affinity of hChE2 is 390 microM [48]. The 10-fold difference in affinity suggests that at commonly encountered serum concentrations, more cocaine will be metabolized by butylcholinesterase than by hChE, and one study found that more than $50 \%$ of cocaine is metabolized by butylcholinesterase [49]. However, one review has suggested that the majority of cocaine is metabolized by hChE1 [47]. 
Variations in plasma cholinesterase activity are clinically important. Several studies have shown that administration of plasma cholinesterase is protective in animal models of acute cocaine toxicity. In a multivariate model, plasma cholinesterase activity was correlated with severe cocaine toxicity in ED patients [50]. There are several phenotypes of human butylcholinesterase, and these may vary in their affinity for cocaine [51]. Interestingly, administration of repeated doses of cocaine may increase plasma butylcholinesterase activity [52].

In summary, cocaine interacts with neurotransmitter transporters, receptors, voltage-gated ion channels, binding proteins and enzymes. The clinical effects of cocaine are triggered through the interactions with transporters, receptors and voltage gated ion channels. While the interaction of cocaine with binding proteins and enzymes does not directly produce cocaine toxicity, changes in the fraction of bound cocaine or in cocaine metabolism will alter the concentration of free cocaine. Any increase in free cocaine increases receptor binding and the clinical effects of cocaine.

\section{Neurotransmitter Receptors and the Clinical Manifesta- tions of Cocaine Poisoning}

\section{Post-Receptor Effects of Cocaine}

Although cocaine binds directly to only a few receptors and transporters, the binding triggers a cascade of activity in multiple neurotransmitter systems. This is shown schematically in Fig. (3). The summation of these pathways produces the toxic effects of cocaine. In this section we will review the clinical effects produced by each of these receptors. binding decrease the behavioral effects of cocaine [55]. Finally, the affinity of various cocaine analogues for DAT accounted for approximately $50 \%$ of the variability in lethality [29]. These studies strongly support the hypothesis that that the major pharmacologic effects of cocaine in the CNS are due to inhibition of the DAT.

There are several studies that further suggest a role for dopamine in cocaine toxicity. SCH 23390 , a selective D1 dopamine antagonist, delays the onset of seizures in cocaine poisoned mice [56]. Sulpiride, a D2 receptor antagonist, had no effect on seizures or mortality. Interestingly, sulpride can prevent some of the behavioral effects of cocaine, suggesting that the pharmacologic and toxic effects of cocaine may be due to different dopamine receptor systems [57].

While some toxic effects of cocaine are mediated by the DAT, the SERT also contributes to cocaine toxicity. In a mouse model, pretreatment with fluoxetine, a potent inhibitor of the SERT, decreased the latency of cocaine-induced convulsions by $53 \%$ and increased the occurrence of seizures in a dose-dependent manner [58]. Similar effects have been reported for other SERT inhibitors [59]. Serotonin receptor antagonists (5HT2 and 5HT3) decrease the incidence of seizures [60]. As cocaine has a very low affinity for serotonin (5HT) receptors [29] ,the effects of 5HT2 and 5HT3 antagonists cannot be due to inhibition of cocaine binding. Rather, cocaine inhibits the SERT causing increased synaptic 5HT concentrations which in turn activates these $5 \mathrm{HT}$ receptors.

The clinical effects due to cocaine inhibition of the NET in the brain appear to be minimal. Modulation of the NET has a minimal effect on cocaine discriminative stimulus stud-

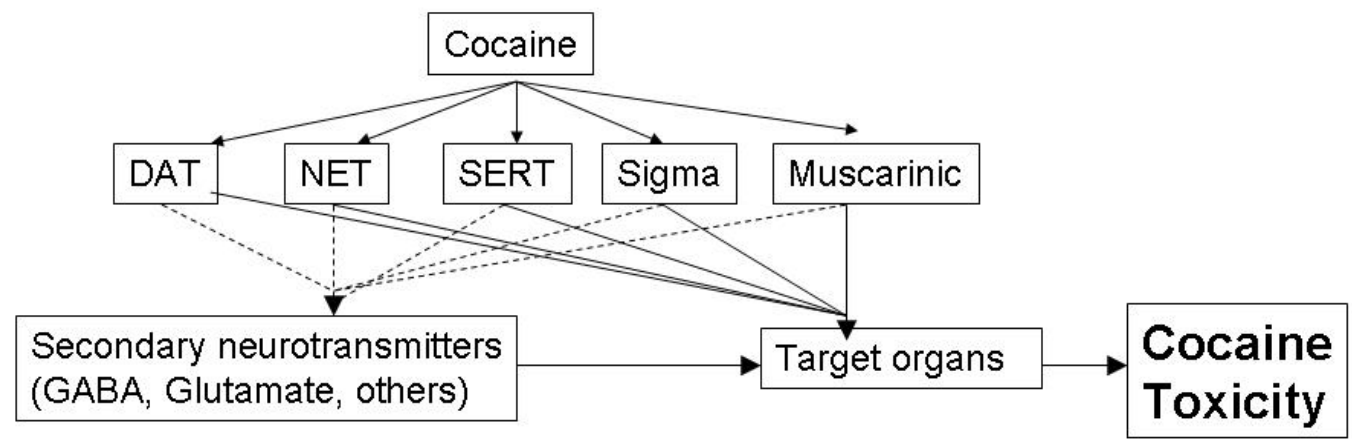

Fig. (3). Cascade of toxicity triggered by cocaine-protein interactions. Primary effects are shown by a solid line while secondary effects are shown by a dashed line.

The DAT is responsible for the major psychostimulant effects of recreational doses of cocaine. Studies of cocaine analogues in monkeys demonstrate the potency of DAT (rather than NET or SERT) inhibition is correlated with the effects on behavior [29]. Mice with no DAT (and decreased SERT) do not develop place-preference (a model for cocaine reward) with cocaine administration [53], and mice with a mutant DAT that does not bind cocaine (and normal SERT) also do not develop place preference [54]. These studies suggest that DAT binding is required for the addictive (and presumably pscychostimulant) properties of cocaine. Studies of non-human primates have also found selective inhibition of the NET and SERT have little effect on the behavioral effects of cocaine, while medications that decrease DAT ies, while modulation of the DAT and SERT have potent effects in this model [61]. Inhibitors of the NET also have minimal effect on cocaine self-administration [62]. Finally, there is no relationship between affinity of cocaine analogues for the NET and their lethality [63]. These data suggest that the interaction between the NET and cocaine contributes little to the toxic effects of cocaine.

Sigma receptors are non-opioid, non-phencyclidine receptors; there are two subtypes: sigma- 1 and sigma- 2 receptors. The sigma- 1 receptor binds to endogenous neurosteroids, and its amino acid sequence is not similar to other proteins [64]. Rimcazole and BD1008, selective sigma antagonists, attenuate the lethal and epileptogenic effects of cocaine in animal models $[65,66]$. Older reports have suggested that 
the sigma receptor agonist SKF-10047attenuates the epileptogenic and lethal effects of cocaine [60, 66-68]. While these data are conflicting and it is unclear which sigma receptor subtype is involved, it appears that sigma receptors contribute to the toxic effects of cocaine.

In the brain, M1 cholinergic receptors are found primarily in the high in striatal and cortical areas while M2 cholinergic receptors are primarily found in the thalamic, nigral and cerebellar areas $[69,70]$. Cocaine attenuates the methacholine induced reduction in heart rate suggesting that it acts as an antagonist at muscarinic receptors [30], but pirenzepine, an M1 receptor antagonist, decreases the lethality and epileptigenic effects of cocaine in a mouse model [60, 71]. These apparently contradictory effects could be explained if cocaine acts as a partial agonist at muscarinic receptors, but the exact effect of cocaine on muscarinic receptors are unclear.

In addition to the clinical effects caused by cocainereceptor interactions, the interaction of cocaine with voltagegated cardiac ion channels is also important. As noted above, at clinically concentrations, cocaine will likely bind to cardiac sodium, potassium and calcium channels. The net clinical effect of cocaine on the heart is caused by interaction with all three ion channels, so it is impossible to state definitively which interaction is the major determinant. However, in studies of anesthetized animals and isolated heart preparations, cocaine concentrations of 10 microM slow intracardiac conduction and prolongs repolarization [72-74]. This is very near the $\mathrm{Ki}$ of cocaine for sodium channels and the major cardiac manifestations ( $\mathrm{pH}$ dependent slowing of intracardiac conduction and myocardial suppression) $[75,76]$ are very consistent with sodium channel poisoning.

The direct interaction of cocaine with the monoamine transporters, sigma and muscarinic receptors, and cardiac ion channels produce the toxic effects of cocaine. However, cocaine toxicity can be altered by pharmacologic manipulation of several other neurotransmitter systems such as the GABA system and the NMDA-glutamate receptor systems. While these systems are not direct targets of cocaine, they are intimately involved in cocaine toxicity.

GABA is the major inhibitory neurotransmitter in the central nervous system. Although cocaine has no direct interaction with the GABA receptor, GABA is the most important neurotransmitter for treatment of cocaine poisoning. Drugs that increase the activity at $\mathrm{GABA}_{\mathrm{A}}$ receptors decrease cocaine induced seizures and lethality in animal models. Likewise $\mathrm{GABA}_{\mathrm{A}}$ antagonists increase cocaine toxicity. There is no evidence that cocaine directly interacts with GABA receptors; rather it affects other neurons that then alter GABA transmission. One proposed mechanism is that activation of D2 dopamine receptors may decrease GABA release leading to increased the CNS excitation observed in cocaine toxicity [77].

Benzodiazepines are the most commonly used medications that alter the activity of $\mathrm{GABA}_{\mathrm{A}}$ receptors. They bind to a unique allosteric site on the $\mathrm{GABA}_{\mathrm{A}}$ receptor and increase the frequency of GABA-mediated chloride channel opening and GABAergic inhibitory neurotransmission. There are at least six rodent studies that support their use for treatment of cocaine poisoning [78-83]. One studied reported a non-significant trend toward increased survival and a marked decrease in seizures [78], while others have reported decreased mortality without a change in the proportion of animals that have cocaine-induced seizures [82, 84]. Administration of flumazenil, a benzodiazepine antagonist, reverses the protective effects of diazepam in mixed cocainediazepam intoxications [85], and administration of a benzodiazepine inverse agonist increases the convulsive effects of cocaine [84]. Overall, there is substantial evidence that drugs acting on the benzodiazepine receptor of the GABAactivated chloride channel alter the convulsive effects of high-dose cocaine.

Other drugs that alter the activity of $\mathrm{GABA}_{\mathrm{A}}$ receptors also alter the effects of cocaine. Phenobarbital and chlormethoxizole act as $\mathrm{GABA}_{\mathrm{A}}$ agonists and are protective against the toxic effects of cocaine in animal models [78, 86]. Finally, SKF-1000330A, an inhibitor of GABA reuptake attenuates seizures and death from cocaine in animals [78]. These data further support the hypothesis that increasing activity at the $\mathrm{GABA}_{\mathrm{A}}$-linked chloride channel attenuates the toxic effects of cocaine.

Glutamate is the major excitatory neurotransmitter in the CNS. The two major glutamate receptors are the NMDA and the AMPA receptors. There are few studies evaluating the role of AMPA in cocaine toxicity. One mouse study suggests that NBQX (an AMPA antagonist) had no effect on cocaine toxicity when given alone, but that it did improve the protection produced by an NMDA antagonist [87]. While AMPA glutamate receptors contribute little to cocaine toxicity, NMDA glutamate receptors have been clearly implicated by multiple studies. MK-801 (a non-competitive NMDA antagonist) dramatically decreases the number of seizures, but has little effect on mortality (unless combined with mechanical ventilation) in cocaine-poisoned rats [79] and mice [56]. Brackett conducted an elegant study demonstrating that competitive NMDA antagonists and antagonists at the glycine binding site of the NMDA receptor complex decreased seizures and lethality, and confirmed that MK-801 attenuates seizures but not lethality [88]. Witkin et al conducted several studies using competitive and non-competitive modulators of the NMDA receptor system and reported that all decreased cocaine-induced convulsions. Furthermore, competitive NMDA inhibitors decreased seizures in a dose-dependent manner [82, 88-90].

In summary, cocaine binds to the DAT, SERT and NET leading to increased synaptic concentrations of these monoamines. This produces more neurotransmitter binding to receptors and ultimately to increased activation of monoamine post-synaptic neurons. The activation of the monoamine receptors, along with interactions with muscarinic and sigma receptors, start the cascade of effects that produce the clinical and toxic effects of cocaine. This cascade includes neurotransmission mediated by the GABA and NMDA receptor systems.

\section{Ratio of Serum to Brain Cocaine Concentration}

Serum concentrations are a reasonable approximation of the cocaine concentration at cardiac ion channels. This is illustrated by comparing the clinical effects observed at a given cocaine concentration with the affinity of the receptors that mediate these effects. Dogs with serum cocaine concen- 
trations near the $\mathrm{Ki}$ of cocaine (10 microM) have slowed intra-cardiac conduction and decreased myocardial contractility consistent with sodium channel antagonism. However, this is not true for CNS receptors. Cocaine must cross the blood brain barrier to enter the CNS. Thus plasma cocaine concentrations may not reflect the cocaine concentration at brain receptors. In a rat model, the brain to plasma ratio was five at one minute and that it increased to nine at fifteen minutes where it was stable for two hours [4]. In a large series of human cocaine poisoning cases, the cocaine concentration in brain was approximately 4 times the blood concentration in the majority of cases (range of 0.7 to 155 times) [91]. These findings suggest that receptors in the brain will be exposed to higher concentrations that are higher than concentrations in serum, but that these concentrations will generally be within an order of magnitude of serum concentrations.

However, recent work now allows us to determine the receptor occupancy at several concentrations of cocaine. Volkow et al. have shown the relative occupancy of the DAT following three clinically relevant doses of cocaine $(0.1,0.3$ and $0.6 \mathrm{mg} / \mathrm{kg}$ iv). This study showed that brain was rapidly transported into the brain, and the serum cocaine concentrations of cocaine were similar to those obtained in previous studies: $0.3+/-0.8,1+/-0.2$ and $1.7+/-0.33 \mathrm{mi}-$ croM. The subjects reported feeling cocaine intoxicated, further demonstrating that these doses are similar to what would be encountered during recreational use. Using PET scanning, this group demonstrated that these doses blocked $47 \%, 60 \%$ and $77 \%$ of the striatal DAT respectively [92]. By comparing the serum concentrations to the observed occupancy, we can make an analogy similar to the cardiac example. These data show that $50 \%$ of DAT will be occupied and that the patient will report feeling the effects of cocaine when the serum cocaine concentration is between 0.3 and 1 microM. While we cannot determine if the same relationship occurs for all of the receptors reviewed in this article, we believe it suggests that serum concentration is a reasonable proxy for the concentration of cocaine at brain receptors.

\section{Cocaine Toxicity: Tying Together Concentrations and Receptor Activation}

While the pharmacology of cocaine is complex and involves several organ systems, cocaine-protein binding is the trigger that activates all of these systems. As the serum concentration of cocaine increases, proteins with a high affinity for cocaine will become saturated, and cocaine will begin to bind to proteins with lower affinities. The $\mathrm{Ki}$ and $\mathrm{Ka}$ values of relevant proteins are plotted with some clinically relevant cocaine concentrations in Fig. (4). This graph highlights some important implications of cocaine pharmacokinetics. At the concentrations commonly encountered in the ED (1-3 microM), the high affinity monoamine transporters will be maximally inhibited. A further increase in cocaine concentration will not increase synaptic monoamine concentrations.

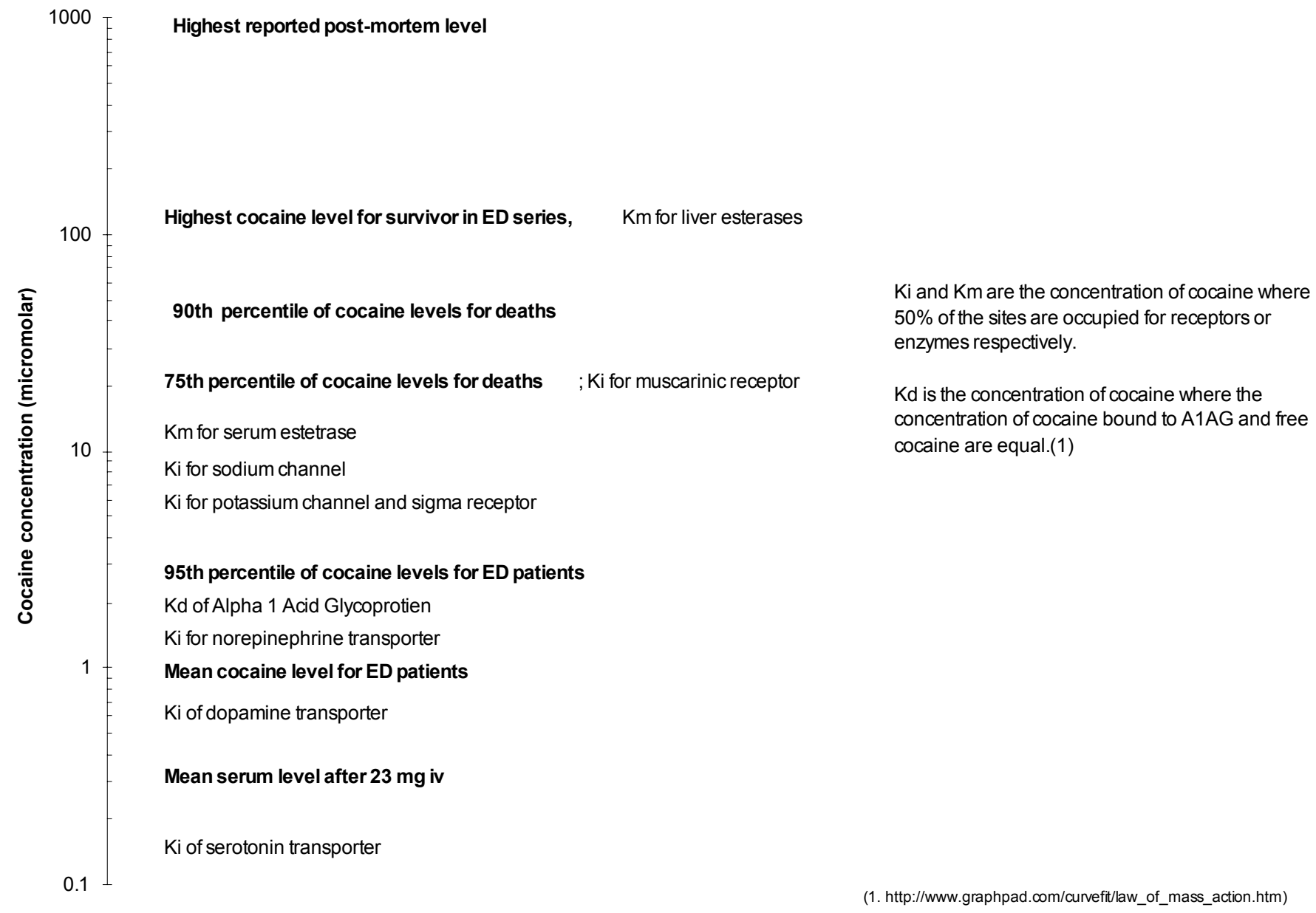

Fig. (4). Serum cocaine concentrations with corresponding clinical effects and protein affinities. 
However, at higher concentrations cocaine will begin to bind to sodium and potassium channels and thus cardiac effects will occur. Animal models of cocaine poisoning have consistently shown slowed intracardiac conduction with cocaine poisoning $[72,74,82,93]$ and there are numerous human reports demonstrating cardiotoxicty due sodium channel antagonism following cocaine overdose $[75,76]$. Cocaine concentrations reported in most fatal cases will also saturate serum binding proteins and esterases, leading to a dramatic increase in free cocaine concentrations and a relative slowing of cocaine metabolism.

By considering cocaine toxicity as a progression, where higher serum concentrations produce activation of new receptor systems, our model allows some clinical predictions. For example, the 10-fold difference in affinity of cocaine for DAT compared to cardiac ion channels means that direct cardiotoxicity will not occur without CNS effects. This model also suggests that the two to three fold variation in serum concentrations observed in low-dose, prospective, fixed dose studies are unlikely to produce substantial differences in toxicity. The increase is not sufficient to allow substantial interaction with receptors beside the monoamine transporters. However, if several factors, such as high doses, male sex and a fall in $\mathrm{pH}$ (such as a seizure) occurred simultaneously, the free cocaine concentrations near the $\mathrm{Ki}$ of sodium channels are possible.

As cocaine interacts directly with only a few proteins that then trigger multiple pathways, it is possible that treatments directed at separate pathways may provide additive protection. For example, patients have been resuscitated from severe cocaine toxicity using a combination of benzodiazepines to treat CNS toxicity and sodium bicarbonate to reverse antagonism of sodium channels $[75,76]$. The combination of diazepam and ziprasidone dramatically decreases the incidence of seizures compared to either treatment alone [83]. Benzodiazepines act on GABA while ziprasidone block dopaminergic and serotonergic receptors. We believe that treating multiple relevant pathways that produce cocaine toxicity may lead to better outcomes. Future studies should evaluate the effect of combining benzodiazepines with serotonergic and NMDA antagonists.

Review of the molecular mechanisms of cocaine toxicity suggests several potential ways to alter an individual's susceptibility to cocaine. For example, differences in the number or affinity of receptors could dramatically alter an individual's response to a dose of cocaine. While genetic differences in receptor number and binding are likely to occur, there is also evidence that environmental effects can play a significant role. Chronic cocaine users have altered regional density of several neurotransmitter receptors and monoamine transporters compared to non-cocaine users [94-98]. This group has suggested that these changes increase the susceptibility of chronic users to severe cocaine toxicity.

Repeated cocaine exposure is not the only way to alter CNS neurotransmitter receptors density. Animal studies have suggested that repeated exposure to many psychiatric medications alters the density of neurotransmitter receptors, including several receptors implicated in the response to cocaine. Longterm exposure to haloperidol alters the behavioral response of rats to cocaine $[99,100]$. Furthermore, a recent study reported that long-term ziprasidone increased cocaine toxicity [101]. We hypothesize that similar changes in humans in response to long-term administration of psychiatric medications will alter their response to cocaine and their susceptibility to cocaine poisoning.

In closing, we hope that the reader will find this review informative and useful. Acute cocaine poisoning is a complex constellation of symptoms involving several organ systems. However, these effects are attributable to activation of a limited number of receptor systems, which occur in a progressive manner that is dependent on the serum cocaine concentration. By applying these principles, we hope to improve the treatment of acute cocaine poisoning.

\section{ACKNOWLEDGEMENTS}

Dr. Heard was supported by DA-020573. Dr. Zahniser was supported by DA-015050.

\section{REFERENCES}

[1] Barnett, G.; Hawks, R.; Resnick, R. Cocaine pharmacokinetics in humans. J. Ethnopharmacol., 1981, 3, 353-66.

[2] Jeffcoat, A.R.; Perez-Reyes, M.; Hill, J.M.; Sadler, B.M.; Cook, C.E. Cocaine disposition in humans after intravenous injection, nasal insufflation (snorting), or smoking. Drug Metab. Dispos., 1989, 17, 153-9.

[3] Cone, E.J. Pharmacokinetics and pharmacodynamics of cocaine. $J$. Anal. Toxicol., 1995, 19, 459-78.

[4] Chow, M.J.; Ambre, J.J.; Ruo, T.I.; Atkinson, A.J., Jr.; Bowsher, D.J.; Fischman, A.W. Kinetics of cocaine distribution, elimination, and chronotropic effects. Clin. Pharmacol. Ther., 1985, 38, 318-24.

[5] Javaid, J.I.; Fischman, M.W.; Schuster, C.R.; Dekirmenjian, H.; Davis, J.M. Cocaine plasma concentration: relation to physiological and subjective effects in humans. Science, 1978, 202, 227-8.

[6] Jenkins, A.J.; Keenan, R.M.; Henningfield, J.E.; Cone, E.J. Correlation between pharmacological effects and plasma cocaine concentrations after smoked administration. J. Anal. Toxicol., 2002, 26, 38292.

[7] Blaho, K.; Logan, B.; Winbery, S.; Park, L.; Schwilke, E. Blood cocaine and metabolite concentrations, clinical findings, and outcome of patients presenting to an ED. Am. J. Emerg. Med., 2000, 18, 593-8.

[8] Williams, R.H.; Maggiore, J.A.; Shah, S.M.; Erickson, T.B.; Negrusz, A. Cocaine and its major metabolites in plasma and urine samples from patients in an urban emergency medicine setting. J. Anal. Toxicol., 2000, 24, 478-81.

[9] Batki, S.L.; Harris, D.S. Quantitative drug levels in stimulant psychosis: relationship to symptom severity, catecholamines and hyperkinesia. Am. J. Addict., 2004, 13, 461-70.

[10] Stephens, B.G.; Jentzen, J.M.; Karch, S.; Mash, D.C.; Wetli, C.V. Criteria for the interpretation of cocaine levels in human biological samples and their relation to the cause of death. Am. J. Forensic Med. Pathol., 2004, 25, 1-10.

[11] Peretti, F.J.; Isenschmid, D.S.; Levine, B.; Caplan, Y.H.; Smialek, J.E. Cocaine fatality: an unexplained blood concentration in a fatal overdose. Forensic Sci. Int., 1990, 48, 135-8.

[12] Mittleman, R.E.; Wetli, C.V. Death caused by recreational cocaine use. An update. JAMA, 1984, 252, 1889-93.

[13] Karch, S.B.; Stephens, B.; Ho, C.H. Relating cocaine blood concentrations to toxicity--an autopsy study of 99 cases. J. Forensic Sci., 1998, 43, 41-5

[14] Volkow, N.D.; Wang, G.J.; Fischman, M.W.; Foltin, R.; Fowler, J.S.; Franceschi, D.; Franceschi, M.; Logan, J.; Gatley, S.J.; Wong, C.; Ding, Y.S.; Hitzemann, R.; Pappas, N. Effects of route of administration on cocaine induced dopamine transporter blockade in the human brain. Life Sci., 2000, 67, 1507-15.

[15] Nayak, P.K.; Misra, A.L.; Mule, S.J. Physiological disposition and biotransformation of $(3 \mathrm{H})$ cocaine in acutely and chronically treated rats. J. Pharmacol. Exp. Ther., 1976, 196, 556-69.

[16] Fischman, M.W.; Schuster, C.R.; Javaid, J.; Hatano, Y.; Davis, J. Acute tolerance development to the cardiovascular and subjective effects of cocaine. J. Pharmacol. Exp. Ther., 1985, 235, 677-82.

[17] Pan, W.J.; Hedaya, M.A. Cocaine and alcohol interactions in the rat: effect of cocaine and alcohol pretreatments on cocaine pharmacokinetics and pharmacodynamics. J. Pharm. Sci., 1999, 88, 1266-74.

[18] Hedaya, M.A.; Pan, W.J. Cocaine and alcohol interactions in naive and alcohol-pretreated rats. Drug Metab. Dispos., 1996, 24, 807-12. 
[19] McCance-Katz, E.F.; Price, L.H.; McDougle, C.J.; Kosten, T.R.; Black, J.E.; Jatlow, P.I. Concurrent cocaine-ethanol ingestion in humans: pharmacology, physiology, behavior, and the role of cocaethylene. Psychopharmacology (Berl), 1993, 111, 39-46.

[20] Farre, M.; de la Torre, R.; Llorente, M.; Lamas, X.; Ugena, B.; Segura, J.; Camí, J. Alcohol and cocaine interactions in humans. $J$. Pharmacol. Exp. Ther., 1993, 266, 1364-73.

[21] Farre, M.; de la Torre, R.; Gonzalez, M.L.; Terán, M.T.; Roset, P.N.; Menoyo, E.; Camí, J. Cocaine and alcohol interactions in humans: neuroendocrine effects and cocaethylene metabolism. J. Pharmacol. Exp. Ther., 1997, 283, 164-76.

[22] Foltin, R.W.; Fischman, M.W. Ethanol and cocaine interactions in humans: cardiovascular consequences. Pharmacol. Biochem. Behav., 1988, 31, 877-83.

[23] Visalli, T.; Turkall, R.; Abdel-Rahman, M.S. Gender differences in cocaine pharmacokinetics in CF-1 mice. Toxicol. Lett., 2005, 155, 3540 .

[24] Morishima, H.O.; Abe, Y.; Matsuo, M.; Akiba, K.; Masaoka, T.; Cooper, T.B. Gender-related differences in cocaine toxicity in the rat. J. Lab. Clin. Med., 1993, 122, 157-63.

[25] Bowman, B.P.; Vaughan, S.R.; Walker, Q.D.; Davis, S.L.; Little, P.J.; Scheffler, N.M.; Thomas, B.F.; Kuhn, C.M. Effects of sex and gonadectomy on cocaine metabolism in the rat. J. Pharmacol. Exp. Ther., 1999, 290, 1316-23

[26] Festa, E.D.; Russo, S.J.; Gazi, F. M.; Niyomchai, T.; Kemen, L.M.; Lin, S.N.; Foltz, R.; Jenab, S.; Quinones-Jenab, V. Sex differences in cocaine-induced behavioral responses, pharmacokinetics, and monoamine levels. Neuropharmacology, 2004, 46, 672-87.

[27] Kosten, T.R.; Kosten, T.A.; McDougle, C.J.; Hameedi, F.A.; McCance, E.F.; Rosen, M.I.; Oliveto, A.H.; Price, L.H. Gender differences in response to intranasal cocaine administration to humans. Biol. Psychiatry, 1996, 39, 147-8.

[28] McCance-Katz, E.F.; Hart, C.L.; Boyarsky, B.; Korsten, T.; Jatlow, $P$. Gender effects following repeated administration of cocaine and alcohol in humans. Subst. Use Misuse, 2005, 40, 511-28.

[29] Ritz, M.C.; Lamb, R.J.; Goldberg, S.R.; Kuhar, M.J. Cocaine receptors on dopamine transporters are related to self-administration of cocaine. Science, 1987, 237, 1219-23.

[30] Sharkey, J.; Ritz, M.C.; Schenden, J.A.; Hanson, R.C.; Kuhar, M.J. Cocaine inhibits muscarinic cholinergic receptors in heart and brain. J. Pharmacol. Exp. Ther., 1988, 246, 1048-52.

[31] Flynn, D.D.; Vaishnav, A.A.; Mash, D.C. Interactions of cocaine with primary and secondary recognition sites on muscarinic receptors. Mol. Pharmacol., 1992, 41, 736-42.

[32] Sharkey, J.; Glen, K.A..; Wolfe, S.; Kuhar, M.J. Cocaine binding at sigma receptors. Eur. J. Pharmacol., 1988, 149, 171-4.

[33] Yasuda, R.P.; Zahniser, N.R.; Dunwiddie, T.V. Electrophysiological effects of cocaine in the rat hippocampus in vitro. Neurosci. Lett., 1984, 45, 199-204.

[34] Lason, W. Neurochemical and pharmacological aspects of cocaineinduced seizures. Pol. J. Pharmacol., 2001, 53, 57-60.

[35] Crumb, W.J. Jr.; Clarkson, C.W. Characterization of cocaine-induced block of cardiac sodium channels. Biophys. J., 1990, 57, 589-99.

[36] Ma, Y.L.; Peters, N.S.; Henry, J.A. Alpha 1-acid glycoprotein reverses cocaine-induced sodium channel blockade in cardiac myocytes. Toxicology, 2006, 220, 46-50.

[37] Crumb, W.J. Jr.; Clarkson, C.W. The pH dependence of cocaine interaction with cardiac sodium channels. J. Pharmacol. Exp. Ther., 1995, 274, 1228-37.

[38] Zhang, S.; Rajamani, S.; Chen, Y.; Gong, Q.; Rong, Y.; Zhou, Z.; Ruoho, A.; January, C.T. Cocaine blocks HERG, but not KvLQT1+ minK, potassium channels. Mol. Pharmacol., 2001, 59, 1069-76.

[39] Ferreira, S.; Crumb, W.J. Jr.; Carlton, C.G.; Clarkson, C.W. Effects of cocaine and its major metabolites on the HERG-encoded potassium channel. J. Pharmacol. Exp. Ther., 2001, 299, 220-6.

[40] Premkumar, L.S. Selective potentiation of L-type calcium channel currents by cocaine in cardiac myocytes. Mol. Pharmacol., 1999, 56, 1138-42.

[41] Edwards, D.J.; Bowles, S.K. Protein binding of cocaine in human serum. Pharm. Res., 1988, 5, 440-2.

[42] Parker, R.B.; Williams, C.L.; Laizure, S.C.; Lima, J.J. Factors affecting serum protein binding of cocaine in humans. J. Pharmacol. Exp. Ther., 1995, 275, 605-10.

[43] Pellinen, P.; Honkakoski, P.; Stenback, FPellinen P, Honkakoski P, Stenbäck F, Niemitz, M.; Alhava, E.; Pelkonen, O.; Lang, M.A.; Pasanen, M. Cocaine N-demethylation and the metabolism-related hepatotoxicity can be prevented by cytochrome P450 3A inhibitors. Eur. J. Pharmacol., 1994, 270, 35-43.

[44] Bornheim, L. M. Effect of cytochrome P450 inducers on cocainemediated hepatotoxicity. Toxicol. Appl. Pharmacol., 1998, 150, 15865 .

[45] Brzezinski, M.R.; Abraham, T.L.; Stone, C.L.; Dean. R.A.; Bosron, W.F. Purification and characterization of a human liver cocaine carboxylesterase that catalyzes the production of benzoylecgonine and the formation of cocaethylene from alcohol and cocaine. Biochem. Pharmacol., 1994, 48, 1747-55.

[46] Dean, R.A.; Zhang, J.; Brzezinski, M.R.; Bosron, W.F. Tissue distribution of cocaine methyl esterase and ethyl transferase activities: correlation with carboxylesterase protein. J. Pharmacol. Exp. Ther. 1995, 275, 965-71.

[47] Warner, A.; Norman, A.B. Mechanisms of cocaine hydrolysis and metabolism in vitro and in vivo: a clarification. Ther. Drug Monit., 2000, 22, 266-70.

[48] Pindel, E.V.; Kedishvili, N.Y.; Abraham, T.L.; Brzezinski, M.R.; Zhang, J.; Dean, R.A.; Bosron, W.F. Purification and cloning of a broad substrate specificity human liver carboxylesterase that catalyzes the hydrolysis of cocaine and heroin. J. Biol. Chem., 1997, 272, 14769-75.

[49] Inaba, T.; Stewart, D.J.; Kalow, W. Metabolism of cocaine in man Clin. Pharmacol. Ther., 1978, 23, 547-52.

[50] Hoffman, R.S.; Henry, G.C.; Howland, M.A.; Weisman, R.S.; Weil, L.; Goldfrank, L.R._Association between life-threatening cocaine toxicity and plasma cholinesterase activity. Ann. Emerg. Med., 1992, 21, 247-53.

[51] Goodall, R. Cholinesterase: phenotyping and genotyping. Ann. Clin. Biochem., 2004, 41, 98-110.

[52] Hoffman, R.S.; Thompson, T.; Henry, G.C.; Hatsukami, D.K.; Pentel, P.R. Variation in human plasma cholinesterase activity during lowdose cocaine administration. J. Toxicol. Clin. Toxicol., 1998, 36, 3-9.

[53] Sora, I.; Hall, F.S.; Andrews, A.M.; Itokawa, M.; Li, X.F.; Wei, H.B.; Wichems, C.; Lesch, K.P.; Murphy, D.L.; Uhl, G.R. Molecular mechanisms of cocaine reward: combined dopamine and serotonin transporter knockouts eliminate cocaine place preference. Proc. Natl. Acad. Sci. USA, 2001, 98, 5300-5.

[54] Chen, R.; Tilley, M.R.; Wei, H.; Zhou, F.; Zhou, F.M.; Ching, S.; Quan, N.; Stephens, R.L.; Hill, E.R.; Nottoli, T.; Han, D.D.; Gu H.H. Abolished cocaine reward in mice with a cocaine-insensitive dopamine transporter. Proc. Natl. Acad. Sci. USA, 2006, 103, 9333-8.

[55] Spealman, R.D.; Madras, B.K.; Bergman, J. Effects of cocaine and related drugs in nonhuman primates. II. Stimulant effects on schedule-controlled behavior. J. Pharmacol. Exp. Ther., 1989, 251,142-9.

[56] Shimosato, K., Marley, R. J., and Saito, T. Differential effects of NMDA receptor and dopamine receptor antagonists on cocaine toxicities. Pharmacol. Biochem. Behav., 1995, 51, 781-8.

[57] Ushijima, I.; Carino, M.A.; Horita, A. Involvement of D1 and D2 dopamine systems in the behavioral effects of cocaine in rats. Pharmacol. Biochem. Behav., 1995, 52, 737-41.

[58] Porrino, L.J.; Ritz, M.C.; Goodman, N.L.; Sharpe, L.G.; Kuhar, M.J.; Goldberg, S.R. Differential effects of the pharmacological manipulation of serotonin systems on cocaine and amphetamine selfadministration in rats. Life Sci., 1989, 45, 1529-35.

[59] O'Dell, L.E.; George, F.R.; Ritz, M.C. Antidepressant drugs appear to enhance cocaine-induced toxicity. Exp. Clin. Psychopharmacol., 2000, 8, 133-41.

[60] Ritz, M.C.; George, F.R. Cocaine-induced convulsions: pharmacological antagonism at serotonergic, muscarinic and sigma receptors. Psychopharmacology (Berl), 1997, 129, 299-310.

[61] Kleven, M.S.; Anthony, E.W.; Woolverton, W.L. Pharmacological characterization of the discriminative stimulus effects of cocaine in rhesus monkeys. J. Pharmacol. Exp. Ther., 1990, 254, 312-7.

[62] Tella, S.R. Effects of monoamine reuptake inhibitors on cocaine selfadministration in rats. Pharmacol. Biochem. Behav., 1995, 51, 68792.

[63] Ritz, M.C.; George, F.R. Cocaine-induced seizures and lethality appear to be associated with distinct central nervous system binding sites. J. Pharmacol. Exp. Ther., 1993, 264, 1333-43.

[64] Su, T.P.; Hayashi, T. Understanding the molecular mechanism of sigma-1 receptors: towards a hypothesis that sigma-1 receptors are intracellular amplifiers for signal transduction. Curr. Med. Chem., 2003, 10, 2073-80

[65] Matsumoto, R.R.; Hewett, K.L.; Pouw, B.; Pouw, B.; Bowen, W.D.; Husbands, S.M.; Cao, J.J.; Hauck, N.A. Rimcazole analogs attenuate 
the convulsive effects of cocaine: correlation with binding to sigma receptors rather than dopamine transporters. Neuropharmacology, 2001, 41, 878-86.

[66] McCracken, K.A.; Bowen, W.D.; de Costa, B.R.; Matsumoto, R.R. Two novel sigma receptor ligands, BD1047 and LR172, attenuate cocaine-induced toxicity and locomotor activity. Eur. J. Pharmacol., 1999, 370, 225-32.

[67] Matsumoto, R.R.; Gilmore, D.L.; Pouw, B.; Bowen, W.D.; Williams, W.; Kausar, A.; Coop, A. Novel analogs of the sigma receptor ligand BD1008 attenuate cocaine-induced toxicity in mice. Eur. J. Pharmacol., 2004, 492, 21-6.

[68] McCracken, K.A.; Bowen, W.D.; Matsumoto, R.R. Novel sigma receptor ligands attenuate the locomotor stimulatory effects of cocaine. Eur. J. Pharmacol., 1999, 365, 35-8.

[69] Perry, E.K.; Smith, C.J.; Perry, R.H.; Whitford, C.; Johnson, M.; Birdsall, N.J. Regional distribution of muscarinic and nicotinic cholinergic receptor binding activities in the human brain. J. Chem. Neuroanat., 1989, 2, 189-99.

[70] Piggott, M.; Owens, J.; O'Brien, J.; Paling, S.; Wyper, D.; Fenwick, J.; Johnson, M.; Perry, R.; Perry, E. Comparative distribution of binding of the muscarinic receptor ligands pirenzepine, AF-DX 384, (R,R)-I-QNB and (R,S)-I-QNB to human brain. J. Chem. Neuroanat., 2002, 24, 211-23.

[71] Ritz, M.C.; George, F.R. Cocaine toxicity: concurrent influence of dopaminergic, muscarinic and sigma receptors in mediating cocaineinduced lethality. Psychopharmacology (Berl), 1997, 129, 311-21.

[72] Wilson, L.D.; Jeromin, J.; Garvey, L.; Dorbandt, A. Cocaine, ethanol, and cocaethylene cardiotoxity in an animal model of cocaine and ethanol abuse. Acad. Emerg. Med., 2001, 8, 211-22.

[73] Parker, R.B.; Perry, G.Y.; Horan, L.G.; Flower, N.C. Comparative effects of sodium bicarbonate and sodium chloride on reversing cocaine-induced changes in the electrocardiogram. J. Cardiovasc. Pharmacol., 1999, 34, 864-9.

[74] Beckman, K. J., Parker, R. B., Hariman, R. J. Gallastegui, J.L.; Javaid, J.I.; Bauman, J.L. Hemodynamic and electrophysiological actions of cocaine. Effects of sodium bicarbonate as an antidote in dogs. Circulation, 1991, 83, 1799-807.

[75] Wang, R.Y. pH-dependent cocaine-induced cardiotoxicity. Am. J. Emerg. Med., 1999, 17, 364-9.

[76] Kerns, W. 2 ${ }^{\text {nd }}$; Garvey, L.; Owens, J. Cocaine-induced wide complex dysrhythmia. J. Emerg. Med., 1997, 15, 321-9.

[77] Centonze, D.; Picconi, B.; Baunez, C.; Borrelli, E.; Pisani, A.; Bernardi, G.; Calabresi, P. Cocaine and amphetamine depress striatal GABAergic synaptic transmission through D2 dopamine receptors. Neuropsychopharmacology, 2002, 26, 164-75.

[78] Hayase, T.; Yamamoto, Y.; Yamamoto, K.; Fukui, Y. Comparison of effect of ethanol and anticonvulsants on cardiovascular drugmodified cocaine toxicity. Pharmacol. Biochem. Behav., 2000, 67, 151-9.

[79] Derlet, R.W.; Albertson, T.E.; Rice, P. Antagonism of cocaine, amphetamine, and methamphetamine toxicity. Pharmacol. Biochem. Behav., 1990, 36, 745-9.

[80] Derlet, R.W.; Albertson, T.E. Diazepam in the prevention of seizures and death in cocaine-intoxicated rats. Ann. Emerg. Med., 1989, 18, 542-6.

[81] Gasior, M.; Carter, R.B.; Goldberg, S.R.; Witkin, J.M. Anticonvulsant and behavioral effects of neuroactive steroids alone and in conjunction with diazepam. J. Pharmacol. Exp. Ther., 1997, 282, 54353.

[82] Witkin, J.M.; Tortella, F.C. Modulators of N-methyl-D-aspartate protect against diazepam- or phenobarbital-resistant cocaine convulsions. Life Sci., 1991, 48, PL51-6.
[83] Cleveland, N.R.; Krier, S.; Heard, K. Ziprasidone, diazepam, or the combination for prevention of cocaine toxicity in a mouse model. Acad. Emerg. Med., 2007, 14,691-4.

[84] Ushijima, I.; Kobayashi, T.; Suetsugi, M.; Watanabe, K.; Yamada, M.; Yamaguchi, K. Cocaine: evidence for NMDA-, beta-carbolineand dopaminergic-mediated seizures in mice. Brain Res., 1998, 797, 347-50.

[85] Derlet, R.W.; Albertson, T.E. Flumazenil induces seizures and death in mixed cocaine-diazepam intoxications. Ann. Emerg. Med., 1994, 23, 494-8.

[86] Gasior, M.; Ungard, J.T.; Witkin, J.M. Chlormethiazole: effectiveness against toxic effects of cocaine in mice. J. Pharmacol. Exp. Ther., 2000, 295, 153-61.

[87] Pouw, B.; Nour, M.; Matsumoto, R.R. Effects of AMPA/kainate glutamate receptor antagonists on cocaine-induced convulsions and lethality in mice. Eur. J. Pharmacol., 1999, 386, 181-6.

[88] Brackett, R.L.; Pouw, B.; Blyden, J.F.; Nour, M.; Matsumoto, R.R. Prevention of cocaine-induced convulsions and lethality in mice: effectiveness of targeting different sites on the NMDA receptor complex. Neuropharmacology, 2000, 39, 407-18.

[89] Witkin, J.M.; Gasior, M.; Schad, C.; Zapata, A.; Shippenberg, T.; Hartman, T.; Slusher, B.S. NAALADase (GCP II) inhibition prevents cocaine-kindled seizures. Neuropharmacology, 2002, 43, 348-56.

[90] Witkin, J.M.; Gasior, M.; Heifets, B.; Tortell, F.C. Anticonvulsant efficacy of N-methyl-D-aspartate antagonists against convulsions induced by cocaine. J. Pharmacol. Exp. Ther., 1999, 289, 703-11.

[91] Spiehler, V.R.; Reed, D. Brain concentrations of cocaine and benzoylecgonine in fatal cases. J. Forensic Sci., 1985, 30, 1003-11.

[92] Volkow, N.D.; Wang, G.J.; Fischman, M.W.; Foltin, R.W.; Fowler, J.S.; Abumrad, N.N.; Vitkun, S.; Logan, J.; Gatley, S.J.; Pappas, N.; Hitzemann, R.; Shea, C.E. Relationship between subjective effects of cocaine and dopamine transporter occupancy. Nature, 1997, 386, 827-30.

[93] Wilson, L.D.; Shelat, C. Electrophysiologic and hemodynamic effects of sodium bicarbonate in a canine model of severe cocaine intoxication. J. Toxicol. Clin. Toxicol., 2003, 41, 777-88.

[94] Mash, D.C.; Pablo, J.; Ouyang, Q.; Hearn, W.L.; Izenwasser, S. Dopamine transport function is elevated in cocaine users. J. Neurochem., 2002, 81, 292-300.

[95] Mash, D.C.; Staley, J.K.; Izenwasser, S.; Basile, M.; Ruttenber, A.J. Serotonin transporters upregulate with chronic cocaine use. J. Chem. Neuroanat., 2000, 20, 271-80.

[96] Mash, D.C.; Staley, J.K. D3 dopamine and kappa opioid receptor alterations in human brain of cocaine-overdose victims. Ann. NY Acad. Sci., 1999, 877, 507-22.

[97] Mash, D.C. D3 receptor binding in human brain during cocaine overdose. Mol. Psychiatry, 1997, 2, 5-6.

[98] Staley, J.K.; Hearn, W.L.; Ruttenber, A.J.; Wetli, C.V.; Mash, D.C. High affinity cocaine recognition sites on the dopamine transporter are elevated in fatal cocaine overdose victims. J. Pharmacol. Exp. Ther., 1994, 271, 1678-85.

[99] Kosten, T.A. Enhanced neurobehavioral effects of cocaine with chronic neuroleptic exposure in rats. Schizophr. Bull, 1997, 23, 20313.

[100] Kosten, T.A.; DeCaprio, J.L.; Nestler, E.J. Long-term haloperidol administration enhances and short-term administration attenuates the behavioral effects of cocaine in a place conditioning procedure. Psychopharmacology (Berl), 1996, 128, 304-12.

[101] Heard, K.; Krier, S.; Zahniser, N.R. The effect of 10 days of ziprasidone administration on acute cocaine toxicity. Hum. Exp. Toxicol., 2007, 